\title{
Heilaígerð - yfirlitsgrein
}

Ólafur Árni Sveinsson læknir ${ }^{1}$, Hilmir Ásgeirsson læknir², Ingvar H. Ólafsson læknir

\section{ÁGRIP}

Heilaígerð er lífshættulegur sjúkdómur sem krefst skjótrar greiningar og meðferðar. Á undanförnum áratugum hafa horfurnar batnað til muna og dánartíðni lækkað úr 50\% i 10\%. Pessi próun endurspeglar bætta myndgreiningu, skurðtækni og sýklalyfjameðferð. Ígerð í heila er staðbundin sýking. Fyrst verður til afmörkuð heilabólga sem próast á tveimur vikum yfir í dauðan vef og samansafn af greftri sem afmarkast af vel blóðnærðu hýði. Sýkingin sem veldur ígerðinni getur borist inn í heilavefinn eftir premur ólíkum leiðum. Í fyrsta lagi bein dreifing sýkingar frá afholum nefs, tönnum, miðeyra eða stikilbeini. Í öðru lagi blóðborin orsök par sem sýking hefur dreift sér frá fjarlægum stað til heilans með tilflutningi blóðs. í priðja lagi í kjölfar heilaaðgerðar eða höfuðáverka par sem rof verður á heilakúpunni. Allt að $30 \%$ heilaígerða eru af ópekktum orsökum par sem upprunalegur sýkingarstaður finnst ekki prátt fyrir ítarlega leit. Algengustu einkennin eru versnandi höfuðverkur og staðbundin taugaeinkenni. Flog koma fram hjá 25-50\%. Meðferð heilaígerða er fólgin í skurðaðgerð og sýklalyfjameðferð.
TTaugadeild Karólínska sjúkrahússins í Stokkhólmi, ${ }^{2}$ smitsjúkdómadeild Karólínska sjúkrahússins í Stokkhólmi, 3taugaskurðdeild Landspitala

Fyrirspurnir: Ólafur Sveinsson olafur.sveinsson@ karolinska.se

Greinin barst 5. júlí 2012, sampykkt til birtingar 11. nóvember 2012.

\section{Inngangur}

Ígerð í heila er staðbundin sýking. Fyrst verður til afmörkuð heilabólga sem próast svo á um tveimur vikum yfir í dauðan vef og samansafn af greftri sem afmarkast af vel blóðnærðu hýði. Algengasta orsök heilaígerðar í gegnum tíðina hefur verið dreifing sýkingar frá nálægum stöðum á höfuðsvæði (eyrum, skútum eða tönnum) til heilans. Tíðni pessara ígerða hefur minnkað til muna, líklega vegna aukinnar sýklalyfjameðferðar. Aðrar ástæður eru blóðbornar sýkingar og sýkingar eftir opinn höfuðáverka eða heilaskurðaðgerð. Allt að 30\% heilaígerða eru af ópekktum orsökum par sem upprunalegur sýkingastaður finnst ekki prátt fyrir ítarlega leit. 1,2

Pó að heilaígerð hafi verið pekkt frá tímum Hippókratesar var fyrsta pekkta skurðaðgerðin við sjúkdómnum framkvæmd árið 1752, af franska skurðlækninum S.F. Morand. ${ }^{3}$ Á hann að hafa með góðum árangri tæmt út heilaígerð í gagnaugablaði (temporal lobe) sem sprottin var frá sáldbeinsskúta (ethmoidal sinus). Árið 1893 gaf breski skurðlæknirinn William Macewen út bók sína Pyogenic Infectious Disease of the Brain and Spinal Cord. Meningitis, Abscess of the Brain, Infective Sinus Thrombosis., Par mælti hann með opinni skurðaðgerð við heilaígerð auk hreinsunar á undirliggjandi sýkingu í skútum. Árið 1918 setti breski læknirinn Warrington fram kenninguna um að heilaígerðir ættu sér annaðhvort rót í sýkingu frá aðlægum stöðum á höfuðsvæði eða frá blóðrásinni. ${ }^{5}$ Á priðja og fjórða áratug síðustu aldar voru settar fram mismunandi aðgerðarmöguleikar við heilaígerð, eins og útsog (aspiration) og skjóðuaðgerð (marsupialization). Síðar varð opin heilaaðgerð, par sem stefnt var að pví að tæma ígerðina í heilu lagi (enucleation), viðtekin meðferð. ${ }^{6,7}$ Árið 1971 kynntu Heineman og samstarfsmenn hans fyrstu tilfellin par sem tekist hafði að lækna heilaígerð með sýklalyfjum einum saman. ${ }^{8}$ Eigi að síður var pað ekki fyrr en með tilkomu tölvusneiðmyndatækninnar að hægt var að greina heilaígerð öðruvísi en með opinni höfuðkúpuaðgerð eða við krufningu.

Fyrir daga tölvusneiðmyndarinnar var dánartíðnin afar há. Á undanförnum áratugum hafa horfurnar batnað til muna og dánartíðnin lækkað úr 50\% fyrir nokkrum áratugum í um 10\% í dag.,10 Pessi próun endurspeglar bætta myndgreiningu, skurðtækni og öflugri sýklalyfjameðferð.11,12 Á móti koma æ fleiri ónæmisbældir einstaklingar sem fá heilaígerð. Par eru gjarnan á ferðinni sjaldgæfar sýkingar. Ónæmisbældir hafa par að auki allt að prefalt hærri dánartíðni vegna heilaígerðar en almennt gerist. ${ }^{12}$ Í pessari grein verður veitt yfirlit um meingerð, klínísk einkenni, greiningu og meðferð heilaígerða.

\section{Aðferðir}

Gerð var leit í PubMed-gagnasafninu. Voru leitarorðin "cerebral abscess", „,brain abscess" og ",cerebritis" notuð. Alls fengust 3908 (423, 3298 og 187) heimildir út frá peirri leit. Áhersla var á greinar sem birst hafa eftir 1990, en í vissum tilvikum leiddi leitin fram mikilvægar eldri heimildir sem voru notaðar. Eingöngu voru lesin ágrip á ensku og íslensku úr ritrýndum tímaritum. Ágrip af fundum eða veggspjöldum voru ekki tekin til greina. Stærri rannsóknir og tilfellaraðir fengu meiri vikt en einstök tilfelli. Settar voru pær kröfur að tilfellaröð yrði að hafa yfir 20 sjúklinga til að vera tekin með. Greinar voru valdar út frá mikilvægi og pýðingu fyrir skrif pessarar yfirlitsgreinar. Af ofantöldum fjölda heimilda voru 535 ágrip lesin. Par af voru lesnar 106 greinar. Af peim voru valdar 59 í pessa grein. 
Tafla I. Bakteríutegundir sem geta gefið til kynna upphafsstað blóðborinnar heilaígerðar. ${ }^{14}$

Hjartapelssýking (endocarditis) - víridans streptókokkar, Staphylococcus aureus

Lungnasýkingar - Streptococcus sp.

Hjartagalli par sem opið er milli hægri og vinstri blóðrásar - Streptococcus sp.

ıðrasýkingar - Enterobacteraciae og loftfirrðar bakteríur

Pvagfærasýkingar - Enterobacteraciae

Sárasýkingar - Staphylococcus aureus og Streptococcus sp.

\section{Meingerd}

Heilavefurinn er vel varinn fyrir sýkingum. Höfuðástæðan er blóð-heilapröskuldurinn, pví eru heilaígerðir sjaldgæfar pó að blóðsýkingar séu pað ekki. Pegar unnið er með dýramódel krefst pað nánast ávallt beinnar sáningar sýkla í heilavefinn til að ígerð myndist. Blóðsýking dugar sjaldnast. ${ }^{13,14}$

Segja má að myndun heilaígerðar gangi í gegnum fjögur stig. ${ }^{14,15}$ Fyrst er pað „snemmbúið heilabólgustig“ (dagur 1-3) par sem sáning sýkils í heilavef leiðir til staðbundinnar bólgu og bjúgmyndunar. Næst er pað „,síðbúið heilabólgustig“ (dagur 4-9). Á pessu stigi stækkar heilabólgusvæðið og myndun dauðs vefjar hefst 1 miðju breytingarinnar. Pegar hringlaga upphleðsla skuggaefnis sést á röntgenmynd er talað um "snemmbúið hýðisstig“ (dagur 10-14). ${ }^{2}$ Síðasta prepið er svo „síðbúið hýðisstig“ (eftir dag 14). Pá hefur ígerðin náð fullum proska og lokast af með myndun hýðis.

Prátt fyrir að heilaígerðin sé tiltölulega vel afmörkuð hafa rannsóknir sýnt að bólguviðbragðið við sýkingunni nær langt út fyrir ígerðina sjálfa (sjá mynd 1). Bólgan og bjúgurinn geta skaðað umlykjandi heilavef. ${ }^{16}$ Í dýratilraunum hefur petta verið skoðað sérstaklega í tengslum við Staphylococcus aureus sýkingu. Kemur í ljós að sýkingin veldur pví að blóð-heilapröskuldurinn lekur.17,18 Sýna rannsóknir mikla bólguvirkni með hækkuðum bólgupáttum (interleukin-1b, tumor necrosis factor-alfa og macrophage inflammatory protein-2), sem geta sést mörgum vikum eftir upphaf sýkingarinnar, prátt fyrir meðhöndlun. ${ }^{17}$ Pess vegna hefur pví verið velt upp hvort bólgueyðandi lyf á borð við barkstera gætu komið að notum. Komið verður að pví síðar.

Prjár leiðir eru fyrir sýkingar að berast inn í heilavefinn: ${ }^{19}$

1) Bein dreifing sýkingar frá afholum nefs, tönnum, miðeyra eða stikilbeini (mastoid). Petta er ástæða milli 12-25\% heilaígerða. Flutningur baktería á sér líklega stað með afturvirku flæði (retrograde flow) með bláæðum. Ekki síst par sem bláæðalokur eru ekki til staðar á pessu svæði. ${ }^{14}$ Á Vesturlöndum hefur tíðni pessarar tegundar ígerðar farið minnkandi, líklega vegna aukinnar sýklalyfjameðferðar við miðeyrnasýkingum..$^{20}$ Í próunarlöndum er hún hins vegar enn algengust (yfir 50\%). ${ }^{21}$ Staðsetning ígerðar getur gefið upphafsstað til kynna. Heilaígerðir í framheilablaði eru gjarnan ættaðar frá afholum nefs (skútum) eða mögulega tönnum, en ígerðir í gagnaugablaði (temporal lobe) eða litla heila frá miðeyrum. Ígerðir í framheilablaði eru algengastar. ${ }^{1,22}$ Streptókokkar (loftháðar og loftfirrðar gerðir) eru algengastir pegar um er að ræða beina dreifingu frá afholum nefs, tönnum eða miðeyrum. Aðrir flokkar baktería sem um getur verið að ræða eru meðal annars Bacteroides sp. (non-fragilis), Fusobacterium sp. og Haemophilus sp. ${ }^{14}$

2) Blóðborin sýking er ástæðan í um 10-20\% tilfella. ${ }^{1,23}$ Í pessum tilfellum er ígerðin gjarnan staðsett á mótum gráa og hvíta efnisins í heilanum og eru ígerðirnar oft fleiri en ein. Tilhneiging blóðborinna sýkinga að hafna á mótum gráa og hvíta efnisins í heilanum er talin orsakast af tregu blóðflæðis á pessum mótum. Einnig er pað tilhneiging blóðborinna sýkinga að taka sér bólfestu á peim stöðum par sem heilinn er skaðaður fyrir. Við blóðborna sýkingu geta pær bakteríutegundir sem ræktast endurspeglað líklegan upphafsstað sýkingarinnar (tafla I).

3) Sýking eftir heilaaðgerð eða höfuðáverka par sem rof verður á heilakúpu er ástæða heilaígerða í um 30-40\% tilfella. ${ }^{24}$ Eftir höfuðáverka er S. aureus langalgengasta bakterían. ${ }^{24}$ Eftir heilaaðgerðir eru pað oft kóagúlasaneikvæðir stafýlókokkar, S. aureus eða Propionibacterium sp. og geta einkennin komið fram löngu (vikum, jafnvel mánuðum) eftir aðgerðina. ${ }^{25}$

Tíðni heilaígerða vegna tækifærissýkinga fer vaxandi par sem í dag eru fleiri ónæmisbældir en áour (vegna illkynja sjúkdóma, ónæmisbælandi lyfjameðferða, HIV-sýkinga og fleira). Áhætta á heilaígerð er ekki síst til staðar hjá einstaklingum með skert Teitilfrumu- og átfrumusvar. ${ }^{26,27}$ Hjá pessum hópi sjást tækifærissýkingar með sníkjudýrum (til dæmis Toxoplasma), sveppum (svo sem Aspergillus, Candida og Cryptococcus sp.) og óvanalegum bakteríum (til dæmis Nocardia sp.). ${ }^{19}$ Pessar tegundir heilaígerða hafa í för með sér háa dánartíðni. ${ }^{28,29}$ Í pessum tilvikum er sérstaklega mikilvægt að sýklafræðileg greining liggi fyrir. Einnig geta berklar valdið heilaígerð og myndað berklahnút (tuberculoma) en ekki verður rætt um pað hér.

\section{Faraldsfræði}

Lítið er vitað um tíðni heilaígerða. Engar stærri faraldsfræðilegar rannsóknir hafa verið framkvæmdar. Ekki eru til rannsóknir á algengi heilaígerða á Íslandi en í Bandaríkjunum (íbúafjöldi rúmar 300 milljónir) er áætlað að um 2000 tilfelli greinist árlega. ${ }^{21,23}$ Heilaígerðir eru allt að fjórum sinnum algengari í próunarlöndum en á Vesturlöndum. ${ }^{19}$

Heilaígerðir eru taldar vera tvisvar til prisvar sinnum algengari meðal karla en kvenna. ${ }^{21,22}$ Hugsanlegar ástæður fyrir pessu eru að karlmenn hafi hærri tíðni vissra áhættupátta heilaígerðar: peir verða oftar fyrir opnum höfuðkúpuáverka, HIV/alnæmi er algengara meðal karla á Vesturlöndum og hið sama á við um áfengismisnotkun og notkun eiturlyfja í æð. Aðrir pekktir áhættupættir fyrir heilaígerð eru sykursýki, langvarandi notkun barkstera og krabbamein.,23,30,31 Áður fyrr var meðfæddur blámahjartasjúkdómur mikilvægur áhættupáttur heilaígerða. ${ }^{14,22}$ Talið er að hærra hlutfall blóðrauða í pessum einstaklingum ásamt hægri til vinstri hjáveitu í hjarta-lungna blóðrás hafi ef til vill stuðlað að aukinni sýkingatíðni. Algengi pessara sýkinga hefur pó farið minnkandi, kannski vegna betri skurðaðgerða við hjartagöllum og fækkun hjartagalla eftir að byrjað var að bólusetja gegn rauðum hundum. ${ }^{22}$

Heilaígerðir geta komið fram á öllum aldri. Á Vesturlöndum eru pær algengastar milli tvítugs og fimmtugs (meðalaldur 35 ár). ${ }^{1}$ Algengið í börnum hefur minnkað verulega miðað við pað sem áður var og er pað talið tengjast öflugri meðferð við miðeyrnabólgum. ${ }^{1,22}$ Í próunarlöndum eru börn enn stór hluti sjúklinga. Sem dæmi má nefna að í stórri suður-afrískri rannsókn voru $70 \%$ sjúklinga undir 30 ára og $43 \%$ undir 18 ára. ${ }^{32}$ 

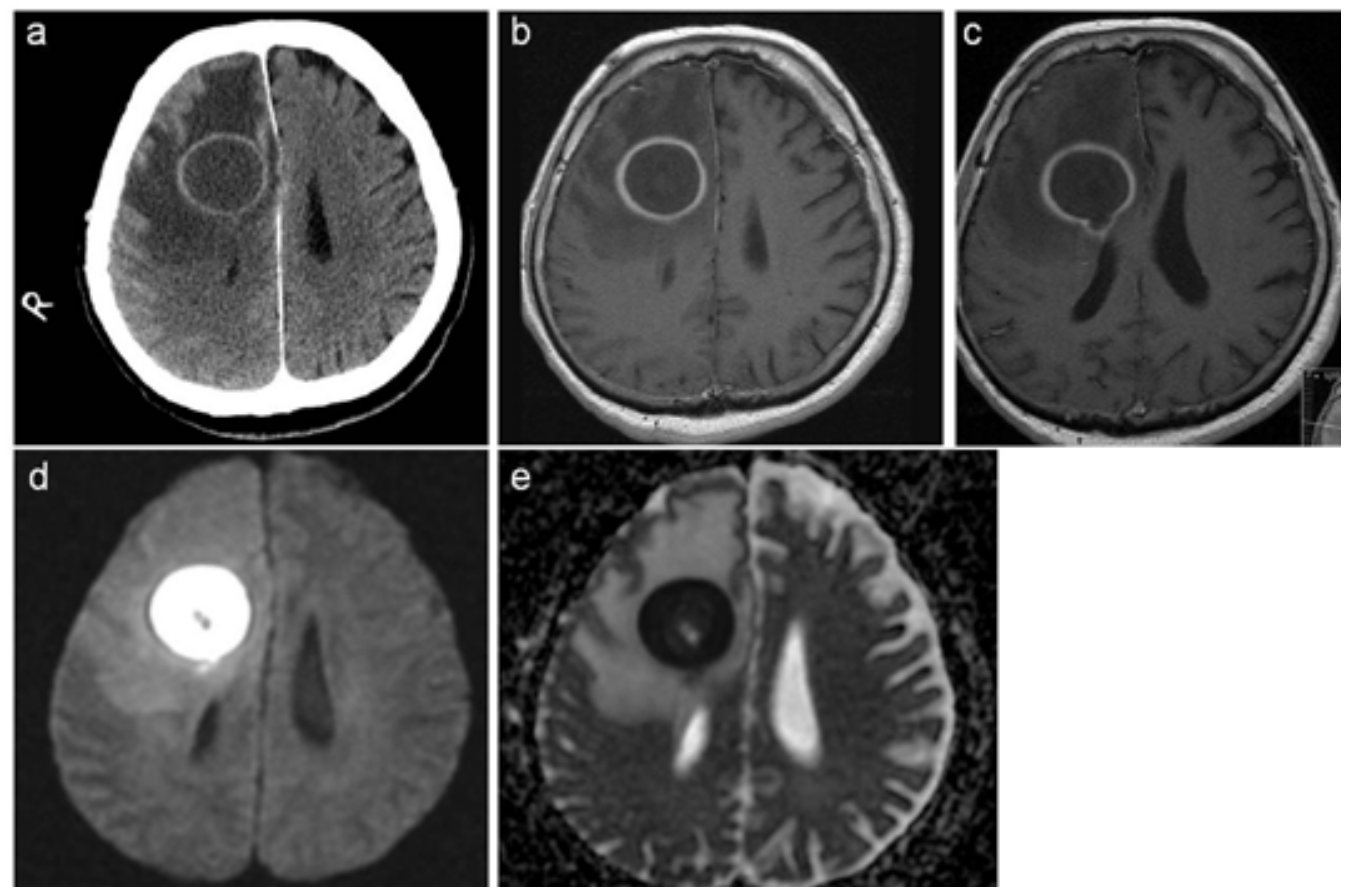

Mynd 1. Eldri karlmaður fann á premur dögum fyrir vaxandi höfuðverk og máttleysi í vinstri líkamshelmingi. Við komu á sjúkrahús á fjórða degi var hann nánast lamaður i vinstri hliðinni og með skerta meðvitund (12 stig á Glasgow-dástigunarkvarðanum). Var hann hitalaus. Gerð var bráðatölvusneiðmynd af heila með skuggaefni (1a) sem sýndi 35x35x40 mm fyrirferð með hringlaga upptöku skuggaefnis í hægra framheilablaði með umliggjandi bjúg og vægri miðlinuhliðrun til vinstri. Strax vaknaði grunsemd um heilaígerd. CRP var $63 \mathrm{mg} / \mathrm{L}$. Segulómskoðun af heila sama dag (T1) eftir gjöf gadólíníums (1b) sýndi fyrirferð með punnri hringlaga upphleðslu. Á annarri samskonar mynd (1c) mátti sjá hvernig ígerðin pynntist í átt að hægra heilahólfi og var nálægt pví að opnast inn í heilahólfið. Til að vera viss um að breytingin væri heilaígerð en ekki æxli var framkvæmd flæðisviktuð (diffusion weighted imaging, DWI) segulómskoðun (1d) sem sýndi aukið segulskyn (hvítt) og gaf frekari grun um ígerð. petta staðfestist með ADC (apparent diffusion coefficient) segulómskoðun (1e) sem sýndi minnkað segulskyn (svart) inni í breytingunni. Var hafin meðferð með barksterum (betametasón $8 m g$ x 2), cefótaxím $3 g$ x 3 og metrónídazól 1g x1 í ð. Gekkst sjúklingurinn undir opna höfuðkúpuaðgerð sama dag og í aðgerðinni kom út gröftur. Dagana á eftir batnađi ástand sjúklings. Komst hann til eðlilegrar meðvitundar og fékk aukinn styrk í vinstri líkamshelming. Ekkert ræktaðist úr blóði en úr ígerðinni ræktaðist Streptococcus milleri sem var næmur fyrir cefótaxím. Ítarlegar rannsóknir leiddu ekki fram upphafsstað sýkingarinnar. Fékk sjúklingur fjögurra vikna meðferð i æð með cefótaxím. Sterarnir voru minnkaðir á premur vikum. Eftir endurhæfingu var til staðar væg máttarminnkun í vinstri líkamshlið.

\section{Klínísk einkenni}

Ekkert einkenni er sértækt við heilaígerð. Sem dæmi um petta hafði aðeins einn sjúklingur í rannsókn með 49 einstaklingum öll pau prjú einkenni sem hafa venjulega verið tengd við heilaígerð: höfuðverk, staðbundin taugaeinkenni og hita. ${ }^{22}$

Algengasta einkennið er vaxandi höfuðverkur (50-90\% tilfella). ${ }^{14,22,31}$ Höfuðverkurinn getur verið útbreiddur jafnt sem staðbundinn og er alveg ósértækur. Erfitt er pví að greina pennan höfuðverk frá öðrum algengari og hættuminni orsökum. Pví getur greining tafist. Við augnbotnaskoðun sést bjúgur í sjóntaugarósi hjá um fjórðungi sjúklinga, en pað gefur til kynna hækkaðan innankúpuprýsting. Hnakkastífleiki er til staðar í allt að fjórðungi tilfella, og getur pað verið tákn um heilaígerð í aftari hnakkagróf (fossa posterior) eða pá teikn um að sýkingin hafi dreift sér til heilahimna. ${ }^{30}$ Skyndileg versnun höfuðverks og hnakkastífni, auk hækkaðs líkamshita, getur bent til pess að ígerðin hafi rutt sér leið inn í heilahólfin eða innanskúmsbilið og eru pá horfur yfirleitt mjög slæmar. ${ }^{14,30}$ Staðbundin taugaeinkenni eru til staðar hjá um $25-50 \%$ tilfella og geta gefið staðsetningu ígerðarinnar til kynna. ${ }^{14,20}$

Hjá um helmingi sjást breytingar á geðsmunum eða persónuleika. Einnig getur orðið breyting á meðvitund, allt frá vægum sljóleika yfir í djúpt meðvitundarleysi. ${ }^{30}$ Flogaköst koma fram hjá 25-50\% í sjúkrahúslegunni. ${ }^{14,30}$ Aðeins um helmingur sjúklinga er

með hækkaðan líkamshita og pví útilokar hitaleysi alls ekki heilaígerð. ${ }^{14,30}$

\section{Greiningarannsóknir}

\section{Myndrannsóknir}

Tölvusneiðmynd (TS) með og án skuggaefnis er oftast fyrsta rannsóknin sem framkvæmd er pegar grunur leikur á heilaígerð. Snemma í sjúkdómsferlinu sést ígerðin sem lágpéttnisvæði sem hleður ekki upp skuggaefni (cerebritis). Síðar í ferlinu sést hin hefðbundna hringlaga upptaka skuggaefnis eftir að ígerðin hefur proskast og hýði myndast (mynd 1). Upphleðslan getur verið pykkari í peim hluta sem snýr að heilaberkinum en pynnri í peim hluta sem snýr að heilahólfunum. Yfirleitt sést einnig umlykjandi bjúgur. Heilaígerðir hafa tilhneigingu til að stækka inn á við í átt að heilahólfunum, í burtu frá hinu betur blóðnærða gráa efni heilabarkarins (mynd 1c). Við petta pynnist miðlægi hluti hýðisins og veldur aukinni hættu á að ígerðin rofni inn í heilahólfin. ${ }^{33}$

Loft inni í fyrirferðinni gefur ígerð til kynna, svo lengi sem heilaaðgerð hefur ekki verið framkvæmd. Oft er hægt að sjá samtímis merki um sýkingar í skútum eða eyrum, pó að stundum purfi sérstakar skúta- eða beinamyndir til að sjá slíkt. Í flestum tilfellum dugar tölvusneiðmynd með skuggaefni til að setja vinnugreininguna heilaígerð en í vissum tilvikum er pörf á segulómskoðun 
(SÓ) sem er mun næmari og sértækari rannsókn. Sérstaklega á petta við pegar kemur að heilabólgu (cerebritis), ígerðum í aftari hnakkagróf, eða pegar greina parf heilaígerð frá helstu mismunagreiningum; æxli eða meinvarpi. ${ }^{14}$ Flæðisviktuð (diffusion) segulómskoðun er afar næm aðferð til að greina heilaígerð (myndir 1d-f) og ekki síst svokallað AD-myndform (apparent diffusion coefficient). ${ }^{34}$ Hvítkornaskann (leukocyte scintgraphy) sýnir fram á virkan bólgustað og getur pví í einstaka tilfellum verið gagnleg viðbótarrannsókn.

\section{Ađrar rannsóknir}

Við skurðaðgerð er nauðsynlegt að senda sýni í almenna bakteríuræktun fyrir loftháðum og loftfirrðum bakteríum. Sé grunur um óvanalegri sýkingar (svo sem sveppi, berkla, sníkjudýr) getur purft sérræktanir eða litanir. Til að útiloka aðrar mismunagreiningar er oft nauðsynlegt að taka sýni til meinafræðilegrar skoðunar (PAD) og frumurannsókna (cytologia). Ávallt er ástæða til að framkvæma Gramslitun á sýninu par sem stundum getur litunin verið jákvæð prátt fyrir neikvæða ræktun. Petta á einkum við ef sýni er tekið eftir gjöf sýklalyfja. ${ }^{31}$

Í allt að 30\% tilfella tekst ekki að finna sýklafræðilega orsök ígerðarinnar. ${ }^{1}$ Greiningarárangur virðist pó geta orðið mun betri við rétta meðhöndlun sýna. ${ }^{6}$ Í allt að priðjungi heilaígerða er um að ræða fleiri en einn sýkil samkvæmt ræktunarniðurstöðum. 10,14,19 Nýrri og næmari greiningaraðferðir (fjölliðugreining á erfðaefni sýkla, 16S rRNA) benda til pess að mun fleiri tegundir baktería eigi pátt í meingerð heilaígerða en áður hefur verið talið. ${ }^{35}$ Petta er afar næm aðferð. Par má greina sýklafræðilega orsök mikils meirihluta heilaígerða. ${ }^{21,36}$ Á petta sérstaklega við um aukinn fjölda loftfirrðra baktería sem greinst hafa í heilaígerðum. Líklegt er að pessi vitneskja muni á næstu árum breyta hugmyndum okkar um meingerð og meðferð heilaígerða. ${ }^{35-37}$

Blóðræktanir eru einungis jákvæðar í um 30\% tilfella ${ }^{37}$ en ættu ávallt að vera framkvæmdar sé grunur um heilaígerð, jafnvel pó sjúklingur sé hitalaus. Einnig er mikilvægt að rækta frá grunuðum upphafsstað sýkingar. ${ }^{30}$ Mænuholsástunga er yfirleitt ekki hjálpleg og er í raun frábending, ekki síst ef teikn um hækkaðan innankúpuprýsting eru til staðar. ${ }^{38}$ Ef jákvæðar ræktanir fást ekki úr ígerðinni og grunur er um samfylgjandi heilahimnubólgu eða sýkingu í heilahólfum (ventriculitis) getur pó verið ástæða til að framkvæma mænuholsástungu. ${ }^{12}$ Blóðpróf koma sjaldnast að miklu gagni við greiningu heilaígerðar. ${ }^{23}$ Ekki sést ávallt hækkun á fjölda hvítra blóðkorna. Mælingar á sökki og c-reaktíftu prótíni (CRP) geta verið innan eðlilegra marka. ${ }^{19}$ Pessar mælingar koma að meira gagni við mat á meðferðarárangri og við eftirfylgd. ${ }^{39}$

\section{Mismunagreiningar}

Heilaæxli og meinvörp eru helstu mismunagreiningar heilaígerðar. Flæðisviktuð segulómskoðun og AD-myndform (apparent diffusion coefficient) greina pó oftast á milli, eins og nefnt var að ofan. Auk pess er hin hringlaga upptaka skuggaefnis frekar punn í heilaígerð. Ef hún er pykk, óregluleg og hnútótt, gefur pað frekar til kynna æxli eða jafnvel sveppaígerð. ${ }^{40}$

Hjá sjúklingi með hita, höfuðverk, breytt hugrænt ástand og staðbundin taugaeinkenni eru aðrar sýkingar en heilaígerð mögu-

\begin{tabular}{l}
$\begin{array}{l}\text { Tafla II. Aðstæður par sem sýklalyfjameðferð við heilaígerð er oft látin nægja } \\
\text { eingöngu. }{ }^{44,22}\end{array}$ \\
\hline Margar ígerðir \\
\hline Ígerð á stað sem erfitt er að nálgast með aðgerð \\
\hline Ígerð er staðsett á viðkvæmu svæði heila (til dæmis við málstöðvar) \\
\hline Heilahimnubólga einnig til staðar \\
\hline Ígerð minni en 2-3 sentímetrar í pvermál \\
\hline Ígerð sem minnkar hratt eftir upphaf sýklalyfjameðferðar \\
\hline Sýking á heilabólgustigi (cerebritis) \\
\hline Sjúklingur of veikur fyrir skurðaðgerð vegna undirliggjandi sjúkdóms \\
\hline
\end{tabular}

legar. Dæmi um slíkar eru innansbastsígerð (subdural empyema), utanbastsígerð (epidural abscess), heilabólga af völdum veira, heilahimnubólga af völdum baktería eða veira eða rof á sveppalíkisæðagúl (mycotic aneurysm). Einstaka sinnum geta breytingar við afmýliserandi sjúkdóm eins og heila- og mænusigg (MS) haft hringlaga upptöku skuggaefnis og par með líkst heilaígerð. Heilavefsblæðing sem er í frásogsferli (resorption) getur einnig líkst heilaígerð. Listeria monocytogenes, Legionella pneumophila og Mycoplasma pneumoniae geta valdið valdið sýkingu í heilastofni sem lítur út eins og ígerð, en er pað ekki. ${ }^{14}$ Pegar kemur að pví að greina ofannefndar mismunagreiningar frá heilaígerð skipar segulómun höfuðsess.

\section{Meðferð}

\section{Lyfjameðferð}

Árangursrík meðferð byggist á réttu sýklalyfjavali. Petta undirstrikar mikilvægi réttrar sýklafræðilegrar greiningar. ${ }^{9}$ Ekki nægir að sýklalyfin sem valin eru hafi drápshæfni gegn tilteknum sýkli, heldur purfa pau einnig að komast inn í heilavefinn, ígerðina sjálfa og halda virkni sinni við tiltölulega lágt pH-gildi. Engar slembirannsóknir eru til á sýklalyfjameðferð heilaígerða. Byggist pví meðferðin á reynslu og vitneskju um eiginleika lyfjanna, ásamt pekkingu á staðbundnu sýklalyfjaónæmi.

Lengi vel var hefðbundin meðferð háskammta penicillín (upp í 24 milljón einingar á sólarhring í 6 skömmtum) og klóramfenikól. Í stað penicillíns hefur nú orðið algengara að nota priðjukynslóðar cefalósporín (cefótaxím, ceftríaxón) par sem pau hafa einnig virkni gegn ýmsum gram-neikvæðum bakteríum og S. aureus. Metrónídazól er afar áhrifaríkt gegn loftfirrðum bakteríum og kemst vel inn í ígerðina. Hefur pað komið í stað klóramfenikóls sem hefur vanmyndunarblóðleysi (aplastic anemia) sem sjaldgæfa en pekkta aukaverkun. Auk pessa er klóramfenikól bakteríuhemjandi en ekki bakteríudrepandi. Pví er fyrsta reynslu (empirical) sýklalyfjameðferðin í dag við heilaígerð yfirleitt priðjukynslóðar cefalóspórín og metrónídazól. Einnig er hægt að nota karbapenemsambönd (svo sem merópenem) sem breiðvirka meðferð. Sumir mæla með að vankómýsíni sé bætt við sem priðja lyfi. Рað hefur meðal annars pann kost að pað vinnur á metisillínónæmum S. aureus (MÓSA) og kóagulasaneikvæðum stafýlokokkum. ${ }^{41,42}$ Hafa ber í huga að betalaktam-sýklalyf geta lækkað krampapröskuld en imípenem er pað lyf sem helst hefur verið tengt aukinni áhættu á flogum hjá sjúklingum með heilaígerð. ${ }^{19} \mathrm{Við}$ alvarlegt penicillínofnæmi er sýklafræðileg greining jafnvel enn mikilvægari. Lyf sem pá kemur til greina að nota eru til dæmis klóramfenikól, kínólónsambönd og klindamýsín. ${ }^{14}$ 
Tafla III. Pættir sem tengdir eru verri horfum við heilaígerð. ${ }^{14,22}$

Einkenni og teikn sem benda til yfirvofandi haulunar við greiningu

Minnkuð̃ meðvitund við greiningu

Stór fyrirferð með prýstingsáhrifum (vaxandi bjúg, miðlínuhliðrun)

Stuttur tími einkenna fyrir greiningu

Seinkun á framkvæmd skurðaðgerðar

Gram-neikvæð sýking

Aðrir undirliggjandi sjúkdómar eđa bælt ónæmiskerfi

Nocardia-sýking

Rof ígerðar inn í heilahólf

Leiðbeiningar um meðferðarlengd eru mismunandi. Oft er mælt með meðferð í æð í 6-8 vikur og par á eftir töflumeðferð í 2-3 mánuði. ${ }^{14}$ Ýmsir hafa mælt með styttri meðferð í æð, allt niður í tvær vikur. ${ }^{22}$ Meðferðarlengdin ræðst pó af pví hve vel sýkingin svarar meðferð. Er pað metið út frá myndrannsóknum (TS/SÓ allt að vikulega, síðan mánaðarlega pangað til upphleðslan er horfin) og einkennum hvers sjúklings fyrir sig. ${ }^{42}$ Skurðaðgerð getur mögulega stytt lengd sýklalyfjameðferðar í æð. Skoða ætti vel samtímis sýkingar í eyra, nefi, skútum og tönnum. Pó að meirihluti sjúklinga purfi einnig á skurðmeðferð að halda er sýklalyfjameðferð í vissum tilfellum látin nægja (tafla II). ${ }^{22,23}$ Hér verður ekki fjallað nánar um meðferð óvanalegri heilaígerða, svo sem af völdum sveppa, berkla eða sníkjudýra.

\section{Skurðmeðferð}

Tilgangur skurðaðgerðar við heilaígerð er prípættur. Í fyrsta lagi til að fá greiningu; í öðru lagi til að minnka fyrirferðina/prýsting; í priðja lagi til að minnka graftarpollinn pannig að virkni sýklalyfja verði árangursríkari. Í höfuðatriðum eru prír skurðaðgerðarmöguleikar við heilaígerð: 1) Útsog (aspiration) og sýnataka gegnum borholu, 2) prívíddarmiðað (sterotactic) útsog og sýnataka, eða 3) opin höfuðkúpuaðgerð með brottnámi ígerðarinnar. Tegund skurðaðgerðar fer eftir staðsetningu og stærð ígerðar, fjölda ígerða og almennu ástandi sjúklings. ${ }^{43,44}$ Segja má að fyrsti kosturinn (útsog í gegnum borholu) sé sá algengasti. Á síðustu árum hefur notkun prívíddarmiðaðrar sýnatöku aukist.

Fjöldi rannsókna hefur staðfest gagnsemi prívíddarmiðaðs útsogs og sýnatöku við heilaígerð. ${ }^{45,46}$ Рað eru margir kostir við pá nálgun. Nálgast má ígerðir án pess að valda miklum skaða á aðliggjandi heilbrigðum taugavef. ${ }^{47} \mathrm{Um}$ er að ræða minna inngrip en við opna höfuðkúpuaðgerð og hefur lægri dánartíðni og fötlun í för með sér. ${ }^{19}$ Á aðferðin ekki síst við ef ígerðin er lítil, liggur djúpt inni í heilanum (stúkunni, djúphnoðum eða heilastofni) eða ef hún er á viðkvæmum stað (til að mynda á málsvæði). ${ }^{48,49}$

Mælt er með opinni aðgerð með brottnámi pegar til staðar eru gasmyndandi ígerðir, margdeilda (multiloculated) ígerðir, sveppaígerðir, ef innankúpuprýstingur er hár, ef ígerðin er í aftari hnakkagróf (posterior fossa) eða eftir höfuðáverka par sem samtímis parf að fjarlægja beinflís sem borist hefur inn í heilavefinn. ${ }^{12,14}$

Æskilegt er að framkvæma skurðaðgerð með sýnatöku eins fljótt og auðið er, pó ekki á heilabólgustiginu. Helst ætti að bíða með sýklalyfjameðferð par til sýni úr ígerðinni hefur fengist. Í vissum tilfellum, til að mynda ef sjúklingurinn er alvarlega veikur með blóðsýkingu, gengur pað ekki.

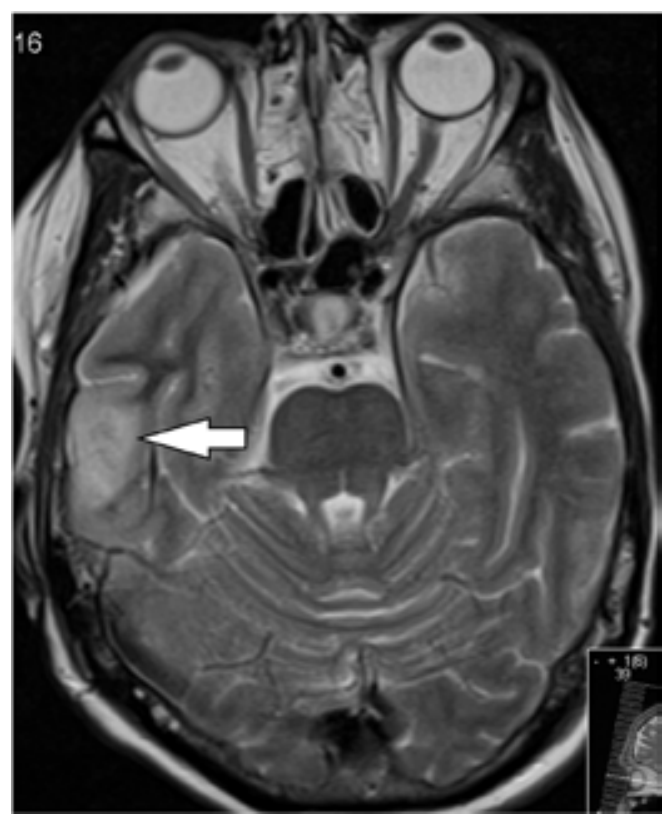

Mynd 2. Eldri kona leitað̇i til læknis vegna verks frá hægra eyra sem úr rann gröftur. Voru einkennin metin sem ytri eyrnabólga og fékk hún eyrnadropa. Daginn eftir fékk hún krampa og var flutt á brádamóttöku. Hún var með háan hita $\left(39,5^{\circ} \mathrm{C}\right)$ og órád. CRP var $365 \mathrm{mg} / \mathrm{L}$. Tölvusneiðmynd af höfði sýndi merki um sýkingu í stikilbeini (mastoid) og vakti grun um heilabólgu i hægra gagnaugablaði (temporal lobe). Segulómskoðun (T1) með gadólínum sýndi bólgu í hægra gagnaugablaði en engin merki um skuggaefnisupphleðslu. Á T2 mynd sást bólgan betur (mynd 2). Krampað hún i tvígang aftur og var meðhöndluð fyrst með fosfeny tóín og síðan leveracítam (Keppra®). Meðferð var hafin með cefótaxím $3 g x 3$ í æð. Frá blóði og nefkokssýni ræktaðist Streptococcus pyogenes. Í kjölfarið var gerð aðgerð á stikilbeini og ræktaðist par bæði S. pyogenes og Staphylococcus aureus. Eftir 11 daga fékk sjúklingur útbrot og skipt var yfir í merópenem $2 g x 3$ i tvær vikur. Eftir að hún útskrifaðist fékk hún ertapenem ( $2 g$ ) í ð einu sinni á dag í 9 daga. Nádi konan sér fullkomlega. Flogaveikimeðferd var hæett eftir eitt ár.

\section{Önnur meðferð}

Notkun barkstera við heilaígerð er umdeild. Í fyrsta lagi minnka sterar bólgu og geta pví dregið úr prýstingsáhrifum og geta jafnvel bjargað lífi ef um hækkaðan innankúpuprýsting er að ræða. ${ }^{50}$ Í öðru lagi geta peir hugsanlega haft neikvæð áhrif á próun sýkingarinnar með pví að minnka hýðismyndun sem lokar af sýkinguna. ${ }^{51}$ Sumir hafa pó fullyrt að barksterarnir geri pað ekki, heldur minnki peir aðeins skuggaefnisupphleðsluna. ${ }^{52}$

Almennt er mælt með gjöf barkstera nokkra daga fyrir og eftir aðgerð til að minnka innankúpuprýsting. ${ }^{39}$ Ein rannsókn sýndi pó fram á hærri dánartíðni meðal sjúklinga sem fengið höfðu barkstera við heilaígerð. ${ }^{53}$ Að öllum líkindum var pó um valbjaga að ræða par sem sjúklingarnir voru afar veikir fyrir. Aðrar rannsóknir hafa ekki sýnt fram á neikvæð áhrif af notkun barkstera hjá sjúklingum með heilaígerð.

Osmótísk pvagræsilyf á borð við mannitól eru stundum notuð við versnandi heilabjúg og hækkuðum innankúpuprýstingi. Meðhöndla ætti flog með staðföstum hætti par sem pau geta hækkað innankúpuprýstinginn enn frekar. Ef flog hafa komið fram í bráðafasanum er mælt með allt að eins árs meðferð, auðvitað lengur ef flogaveiki próast. ${ }^{43}$ Einnig hefur meðferð í súrefniskúti (hyperbaric oxygen therapy) verið reynd sem viðbótarmeðferð án pess pó að gagnsemi hennar hafi verið að fullu sannreynd. ${ }^{54}$ 


\section{Horfur og eftirfylgd}

Á undanförnum áratugum hafa horfur sjúklinga með heilaígerð batnað gríðarlega. Endurspeglar petta bætta sjúkdómsgreiningu, skurðtækni og öflugri sýklalyf. ${ }^{22}$ Dánartíðni við heilaígerð er í dag um 10\% $\%^{9,12,32}$ en var milli $40-60 \%$ fyrir daga tölvusneiðmyndarinnar. ${ }^{55,56}$ Síðastliðinn áratug hafa komið fram rannsóknir par sem stór hluti pátttakenda eru ónæmisbældir. Par hefur dánartíðnin verið hærri, eða milli 17- 32\%.27,43

Helmingur peirra sem lifa af ná sér að fullu. Hinn helmingurinn býr við einhverja viðvarandi fötlun á borð við máttarminnkun í útlimum, flogaveiki eða skerta vitsmunagetu. Í töflu III má sjá pá pætti sem spá fyrir um verri horfur. Rétt er að draga fram nokkra peirra. Vel pekkt er að sjúklingar með lækkað meðvitundarstig og/ eða alvarleg staðbundin taugaeinkenni við greiningu hafa verri horfur. ${ }^{55,57}$ Rof ígerðar inn í heilahólfin hefur lengi verið pekkt sem afar slæmur forspárpáttur. ${ }^{30}$ Í einni rannsókn dóu 85\% af 129 sjúklingum sem orðið höfðu fyrir rofi inn í heilahólfin. ${ }^{57}$ Í annarri rannsókn frá Japan var dánartíðnin mun lægri (39\%). ${ }^{55}$ Ónæmisbældir sjúklingar með heilaígerð af völdum Nocardia eða Listeria hafa prisvar sinnum hærri dánartíðni miðað við hefðbundnar sýklafræðilegar orsakir. ${ }^{27,58}$ Peir pættir sem geta spáð fyrir um betri horfur eru: ungur aldur, engin alvarleg taugaeinkenni við greiningu eða alvarlegir undirliggjandi sjúkdómar. ${ }^{22,30}$

Allt að helmingur sjúklinga (10-50\%) verður fyrir bakslagi eða endurkomu sjúkdóms. Petta pýðir að fylgja verður sjúklingum afar náið, í að minnsta kosti eitt ár. Nauðsynlegt er að sjá að fyrirferðin, bólgan og upphleðsla skuggaefnis hverfi. ${ }^{59}$ Ef ígerðin minnkar ekki við meðferð er rétt að endurtaka skurðaðgerð. Hið sama á við ef klínískt ástand sjúklings versnar. Ekki síst á pað við ef sýklafræðileg greining liggur ekki fyrir.

\section{Samantekt}

Heilaígerð er lífshættulegt sjúkdómsástand sem krefst skjótrar greiningar. Раð sem gerir greininguna jafnan erfiða er að klínísk einkenni eru ósértæk. Aðeins í helmingi tilfella er líkamshiti hækkaður. Við greiningu skipar segulómskoðun höfuðsess. Ekki síst vegna pess að heilaæxli og meinvörp eru helstu mismunagreiningar. Árangursrík meðferð byggist á réttu sýklalyfjavali og skurðaðgerð í náinni samvinnu mismunandi sérgreinalækna. Mikilvægt er að meðhöndla krampa af festu par sem peir geta hækkað innankúpuprýsting og gert horfurnar verri.

\section{Heimildir}

1. Roche M, Humphreys H, Smyth E, Phillips J, Cunney R, McNamara E, et al. A twelve-year review of central nervous system bacterial abscesses; presentation and aetiology. Clin Microbiol Infect 2003; 8: 803-9.

2. Lu CH, Chang WN, Lin YC, Tsai NW, Liliang PC, Su $\mathrm{TM}$, et al. Bacterial brain abscess: microbiological features, epidemiological trends and therapeutic outcomes. QJM 2002; 95: 501-9.

3. Canale DJ. William Macewen and the treatment of brain abscesses: revisited after one hundred years. J Neurosurg 1996; 84: 133-42.

4. Macewen W. Pyogenic Infective Disease of the Brain an Spinal Cord. Meningitis, Abscess of the Brain, Infective Sinus Thrombosis. James Maclehose and Sons, Glasgow Sinus
1893.

5. Warrington WB. Abscess of the brain. QJM 1918; 2: 141-64

6. King JEJ. The treatment of the brain abscess by unroofing and temporary herniation of abscess cavity with avoidance of usual drainage methods, with notes on the management of hernia cerebri general. Surg Gynecol Obste 1924; 39: 554-68.

7. Dandy WE. Treatment of chronic abscesses of the brain by tapping. Preliminary note. JAMA 1926; 87: 1477-8.

8. Heineman HS, Braude AI, Osterholm JL. Intracranial suppurative disease. Early presumptive diagnosis and successful treatment without surgery. JAMA 1971; 218: 1542-7.

9. Cavusoglu $\mathrm{H}$, Kaya RA, Türkmenoglu ON, Colak I, Aydin Y. Brain abscess: analysis of results in a series of 51 patients with a combined surgical and medical approach during an 11-year period. Neurosurg Focus 2008; 24: E9.

10. Moorthy RK, Rajshenkar V. Management of brain abscess an overview. Neurosurg Focus 2008; 24: E3.

11. Alderson D, Strong AJ, Ingham HR, Selkon JB. Fifteen-year review of the mortality of brain abscess. Neurosurgery 1981; 8: 1-6.

12. Erdogan E, Cansever T. Pyogenic brain abscess. Neurosurg Focus 2008; 24: E2

13. Molinari GF, Smith L, Goldstein, Satran R. Brain abscess from septic cerebral embolism: an experimental model. Neurology 1973; 23: 1205-10.

14. Mathisen GE, Johnson JP. Brain abscess. Clin Infect Dis 1997; 25: 763-79.

15. Britt RH, Enzmann DR, Yeager AS. Neuropathological and computerized tomographig findings in experimental brain abscess. J Neurosurg 1981; 55: 590-603

16. Kielian T. Immunopathogenesis of brain abscess. J Neuroinflammation 2004; 1: 16.
17. Kielian T, Esen N, Liu S, Phulwani NK, Syed MM, Phillips $\mathrm{N}$, et al. Minocycline modulates neuroinflammation independently of its antimicrobial activity in staphylococcus aureus-induced brain abscess. Am J Pathol 2007; 171: 1199-214.

18. Kielian T, Esen N, Bearden ED. Toll-like receptor 2 (TLR2) is pivotal for recognition of $\mathrm{S}$. aureus peptidoglycan but not intact bacteria by microglia. Glia 2005; 49: 567-76.

19. Bernardini GL. Diagnosis and management of brain abscess and subdural empyema. Curr Neurol Neurosci Rep 2004; 4: 448-56.

20. Sharma R, Mohandas K, Cooke RP. Intracranial abscesses: changes in epidemiology and management over five decades in Merseyside. Infection 2009; 37: 39-43.

21. Menon S, Bharadwaj R, Chowdhary A, Kaundinya DV, Palande DA. Current epidemiology of intracranial abscesses: a prospective 5 year study. J Med Microbiol 2008; 57: 1259-68

22. Carpenter J, Stapleton S, Holliman R. Retrospective analysis of 49 cases of brain abscess and review of the literature. Eur J Clin Microbiol Infect Dis 2007; 26: 1-11.

23. Mamelak AN, Mampalam TJ, Obana WG, Rosenblum ML. Improved management of multiple brain abscesses: a combined surgical and medical approach. Neurosurgery 1995; 36: 76-85.

24. Yang KY, Chang WN, Ho JT, Wang HC, Lu CH. Postneurosurgical nosocomial bacterial brain abscess in adults. Infection 2006; 34: 247-51.

25. Kranick SM, Vinnard C, Kolson DL. Propionibacterium acnes brain abscess appearing 10 years after neurosurgery. Arch Neurol 2009; 66: 793-5.

26. Casey AT, Wilkins P, Uttley D. Aspergillosis infection in neurosurgical practice. Br J Neurosurg 1994; 8: 31-9.

27. Loeffler JM, Bodmer T, Zimmerli W, Leib SL. Nocardia brain abscess: observation of treatment strategies and outcome in Switzerland from 1992 to 1999. Infection 2001; 29: 337-41.

28. Kennedy KJ, Chung KH, Bowden FJ, Mews PJ, Pik JH, Fuller JW. A cluster of nocardial brain abscesses. Surg Neurol 2007; 68: 43-9.

29. Asgeirsson H, Sigurdardottir B. Sýking af völdum nókardíu í ónæmisbældum einstaklingi. Læknablaðið 2010; 96: 423-5.

30. Seydoux C, Francioli P. Bacterial brain abscesses: factors influencing mortality and sequelae. Clin Infect Dis 1992 15: 394-401.
31. Kao PT, Tseng HK, Liu CP, Su SC, Lee CM. Brain abscess: clinical analysis of 53 cases. J Microbiol Immunol Infect 2003; 36: 129-36.

32. Nathoo N, Nadvi SS, Narotam PK, van Dellen JR. Brain abscess: management and outcome analysis of a computed tomography era experience with 973 patients. World Neurosurg 2011; 75: 716-26.

33. Karampekios S, Hesselink J. Cerebral infections. Eur Radiol 2005; 15:485-493.

34. Chang SC, Lai PH, Chen WL, Weng HH, Ho JT, Wang JS. Diffusion-weighted MRI features of brain abscess and cystic or necrotic brain tumors: comparison with conventional MRI. Clin Imaging 2002; 26: 227-36.

34. Al Masalma M, Armougom F, Scheld WM, Dufour $\mathrm{H}_{,}$ Roche PH, Drancourt $\mathrm{M}$, et al. The expansion of the microbiological spectrum of brain abscesses with use of multiple $16 \mathrm{~S}$ ribosomal DNA sequencing. Clin Infect Dis 2009; 48: 1169-78.

36. Keller PM, Rampini SK, Bloemberg GV. Detection of a mixed infection in a culture-negative brain abscess by broad-spectrum bacterial 16S rRNA gene PCR. J Clin Microbiol 2010; 48: 2250-2.

37. Tsai JC, Teng LJ, Hsueh PR. Direct detection of bacterial pathogens in brain abscesses by polymerase chain reaction amplification and sequencing of partial $16 \mathrm{~S}$ ribosomal deoxyribonucleic acid fragments. Neurosurgery 2004; 55: 1154-62.

38. Hasbun R, Abrahams J, Jekel J, Quagliarello VJ. Computed tomography of the head before lumbar puncture in adults with suspected meningitis. N Engl J Med 2001; 345: 172733.

39. Hakan T, Ceran N, Erdem I, Berkman MZ, Göktas P. Bacterial brain abscesses: an evaluation of 96 cases. J Infect 2006; 52: 359-66.

40. Haimes AB, Zimmerman RD, Morgello S, Weingarten K, Becker RD, Jennis R, et al. MR imaging of brain abscesses. AJR Am J Roentgenol 1989; 152: 1073-85.

41. Gilbert DN, Moellering RC, Eliopoulos GM, Chambers HF, Saag MS (Eds). The Sanford guide to antimicrobial therapy. $3^{\text {th }}$ ed. Antimicrobial Therapy, Sperryville 2009.

42. Honda $\mathrm{H}$, Warren D. Central nervous system infections: meningitis and brain abscess. Infect Dis Clin N Am 2009; 23: 609-23.

43. Lu CH, Chang WN, Lui CC. Strategies for the management of bacterial brain abscess. J Clin Neurosci 2006; 13: 979-85. 
44. Smith SJ, Ughratdar I, MacArthur DC. Never go to sleep on undrained pus: a retrospective review of surgery for intraparenchymal cerebral abscess. Br J Neurosurg 2009; 23: 412-7.

45. Hsieh PC, Pan HC, Chung WY, Lee LS. Computerized tomography - guided stereotactic aspiration of brain abscesses; experience with 28 cases. Zhonghua Yi Xue Za Zhi (Tapei) 1999; 62: 341-9.

46. Nakajima H, Iwai Y, Yamanaka K, Kishi H. Successful treatment of brainstem abscess with stereotactic aspiration. Surg Neurol 1999; 52: 445-8.

47. Boviatsis EJ, Kouyialis AT, Stranialis G, Korfias S, Sakas DE. CT-guided stereotactic aspiration of brain abscesses. Neurosurg Rev 2003; 26: 206-9.

48. Wild AM, Xuereb JH, Marks PV, Gleave JR. Computerized tomoraphic stereotaxy in the management of 200 consecutive intracranial mass lesions. Analysis of indications, benefits and outcome. Br J Neurosurg 1990; 4: 407-15.
49. Lutz TW, Landolt H, Wasner M, Gratzl O. Diagnosis and management of abscesses in the basal ganglia and thalamus: a survey. Acta Neurochir (Wien) 1994; 127: 91-8.

50. Bloch O, Papadopoulos MC, Manley GT, Verkman AS. Aquaporin-4 gene deletion in mice increases focal edema associated with staphylococcal brain abscess. J Neurochem 2005; 95: 254-62.

51. Hakan T. Management of bacterial brain abscesses. Neurosurg Focus 2008; 24 (6): E4

52. Schroeder KA, McKeever PE, Schaberg DR, Hoff JT. Effect of dexamethasone on experimental brain abscess. J Neurosurg 1987; 66: 264-9.

53. Mampalam TJ, Rosenblum ML. Trends in the management of bacterial brain abscesses: a review of 102 cases over 17 years. Neurosurgery 1988; 23: 451-8.

54. Kurschel S, Mohia A, Weigl V, Eder HG. Hyperbaric oxygen therapy for the treatment of brain abscess in children. Childs Nerv Syst 2006; 22: 38-42.
55. Takeshita M, Kagawa M, Izawa M, Takakura K. Current treatment strategies and factors influencing outcome in patients with bacterial brain abscess. Acta Neurochir (Wien) 1998; 140: 1263-70.

56. Xiao F, Tseng MY, Teng LJ, Tseng HM, Tsai JC. Brain abscess: clinical experience and analysis of prognostic factors. Surg Neurol 2005; 63: 442-50.

57. Yang SY. Brain abscess: a review of 400 cases. J Neurosurg 1981; 55: 794-9.

58. Cone LA, Leung MM, Byrd RG, Annunziata GM, Lam RY, Herman BK. Multiple cerebral abscesses because of Listeria monocytogenes: three case reports and a literature review of supratentorial listerial brain abscess(es). Surg Neurol 2003; 59: 320-8.

59. Whelan MA, Hilal SK. Computed tomography as a guide in the diagnosis and follow-up of brain abscesses. Radiology 1980; 135: 663-71.

\section{ENGLISH SUMMARY}

\section{Brain abscess - overview}

Sveinsson OA, Asgeirsson $\mathrm{H}$, Olafsson $\mathrm{IH}$

Brain abscess is a life threatening illness, demanding rapid diagnosis and treatment. Its development requires seeding of an organism into the brain parenchyma, often in an area of damaged brain tissue or in a region with poor microcirculation. The lesion evolves from a cerebritis stage to capsule formation. Brain abscesses can be caused by contiguous or haematogenous spread of an infection, or by head trauma/ neurosurgical procedure. The most common presentation is that of

have been reported in up to $50 \%$ of cases. Focal neurological deficits may be present, depending on the location of the lesion. Treatment of a brain abscess involves aspiration or excision, along with parenteral antibiotic therapy. The outcome has improved dramatically in the last decades due to improvement in diagnostic techniques, neurosurgery, and broad-spectrum antibiotics. The authors provide an overview of the pathogenesis, diagnosis and management of brain abscesses. headache and vomiting due to raised intracranial pressure. Seizures

Keywords: cerebral abscess, cerebritis, magnetic resonance imaging, antibiotic treatment, surgical treatment.

Correspondence: Olafur Sveinsson, olafur.sveinsson@karolinska.se

${ }^{1}$ Department of Neurology, Karolinska University Hospital, Stockholm, Sweden. ${ }^{2}$ Department of Infectious Diseases, Karolinska University Hospital, Stockholm, Sweden. ${ }^{3}$ Department of Neurosurgery, Landspitali The University Hospital of Iceland, Reykjavik. 